\title{
The Reactivity of Niobium and Tantalum Pentahalides with
}

\section{Imines}

Fabio Marchetti ${ }^{\mathrm{a}, *}$, Guido Pampaloni ${ }^{\mathrm{a}}$, Stefano Zacchini ${ }^{\mathrm{b}}$

${ }^{a}$ Università di Pisa, Dipartimento di Chimica e Chimica Industriale, Via Moruzzi 13, I-56124 Pisa, Italy

b Dipartimento di Chimica Industriale "Toso Montanari”, Università di Bologna, Viale Risorgimento 4, I-40136 Bologna, Italy

Received......; accepted

* Corresponding author. Tel.: +390502219245. E-mail address: fabio.marchetti1974@unipi.it Webpage: http://www.dcci.unipi.it/fabio-marchetti.html 


\begin{abstract}
The reactivity of $\mathrm{NbCl}_{5}, \mathrm{NbF}_{5}$ and $\mathrm{TaCl}_{5}$ with a selection of commercial imines was investigated for the first time by using dichloromethane as reaction medium. $\mathrm{NbCl}_{5}$ reacted with $\mathrm{Ph}_{2} \mathrm{C}=\mathrm{NH}$, in 1:2 molar ratio, affording $\left[\mathrm{Ph}_{2} \mathrm{C}=\mathrm{NH}_{2}\right]\left[\mathrm{NbCl}_{5}\left(\mathrm{~N}=\mathrm{CPh}_{2}\right)\right], \mathbf{1}$, in $55 \%$ yield, as result of imine selfprotonation. The iminium salt $\left[\mathrm{PhCH}=\mathrm{NH}^{t} \mathrm{Bu}\right]\left[\mathrm{NbCl}_{6}\right]$, 2, was isolated in $52 \%$ yield from $\mathrm{NbCl}_{5}$ and $\mathrm{PhCH}=\mathrm{N}^{\mathrm{t}} \mathrm{Bu}\left(1: 1\right.$ molar ratio), while a low yield of $\left[{ }^{t} \mathrm{Bu}_{2} \mathrm{C}=\mathrm{NH}_{2}\right]\left[\mathrm{NbCl}_{6}\right], \mathbf{3}$, was identified from $\mathrm{NbCl}_{5} /{ }^{t} \mathrm{Bu}_{2} \mathrm{C}=\mathrm{NH}$. The 1:1 reactions of $\mathrm{NbF}_{5}$ with $\mathrm{Ph}_{2} \mathrm{C}=\mathrm{NH}$ and $\mathrm{PhCH}=\mathrm{N}^{\mathrm{t}} \mathrm{Bu}$ were accompanied by electron interchange and led to the isolation of the salts $\left[\mathrm{Ph}_{2} \mathrm{C}=\mathrm{NH}_{2}\right]\left[\mathrm{NbF}_{6}\right], 4$, and $\left[\mathrm{PhCH}=\mathrm{NH}^{\mathrm{t} B u}\right]\left[\mathrm{NbF}_{6}\right], \quad 5$, respectively, in ca. $50 \%$ yields. Few crystals of $\left[\mathrm{Ph}_{2} \mathrm{C}=\mathrm{NH}_{2}\right]_{2}\left[\mathrm{Ta}_{2} \mathrm{Cl}_{10} \mathrm{O}\right]$, 6, were recovered from $\mathrm{TaCl}_{5} / \mathrm{Ph}_{2} \mathrm{C}=\mathrm{NH}$, the anion being probably generated by the action of adventitious water. Compounds 1-6 were characterized by elemental analysis, IR and NMR spectroscopy. The structures of 1, 4 and $\mathbf{6}$ were ascertained by X-ray diffraction studies.
\end{abstract}

Keywords: Niobium Pentahalides, Tantalum Pentahalides, Imines, Benzophenone Imine, Azavinylidene

\title{
1. Introduction
}

The chemistry of niobium and tantalum pentahalides, $\mathrm{MX}_{5}[1]$, has experienced a significant progress in the last decade, encouraged by cost effectiveness, low toxicity of the metal elements and unusual reactivity patterns [2]. As a matter of fact, $\mathrm{MX}_{5}$ have found increasing application as catalytic precursors in metal mediated organic synthesis [3], and also many aspects of the coordination chemistry with oxygen [4], nitrogen [5] and soft donors [6] have been elucidated in the recent years. In general, the polynuclear structure of $\mathrm{MX}_{5}$ undergoes cleavage by the addition of one equivalent of a neutral Lewis base (L) in a non coordinating solvent; this cleavage usually takes 
place selectively in either symmetric or asymmetric mode, depending on the nature of both $\mathrm{X}$ and $\mathrm{L}$ [4c, $5 \mathrm{c}]$. In the case of symmetric cleavage, neutral complexes of formula $\mathrm{MX}_{5} \mathrm{~L}$ can be generated, whereas the ionic complexes $\left[\mathrm{MX}_{4} \mathrm{~L}_{2}\right]\left[\mathrm{MX}_{6}\right]$ are the result of the asymmetric rupture [7]. The $\left[\mathrm{MX}_{6}\right]^{-}$anions are quite stable, the stability decreasing on moving down the halogen group [4c], and are suitable to the stabilization of organic cations, including otherwise reactive cations [2b, $4 b-c, 8]$. In those cases in which the reactions of $\mathrm{MX}_{5}$ with organic compounds are non selective, the formation of $\left[\mathrm{MX}_{6}\right]^{-}$salts of protonated species is sometimes observed [9]. Usually, both adventitious water and the activation of the organic substrate are possible sources of protonation.

To the best of our knowledge, the direct interaction of $\mathrm{MX}_{5}$ with imines has not been investigated heretofore. Herein, we describe the results of our study on the reactions of $\mathrm{MX}_{5}$ with limited amounts (1-2 molar equivalents) of three commercial imines, i.e. benzophenone imine, Nbenzylidene-tert-butylamine and 2,2,4,4-tetramethyl-3-pentanone imine. The reactions were carried out in dichloromethane, i.e. a non coordinating, privileged solvent for studying the coordination chemistry of high valent transition metal halides [4c-d, 10]. The isolated metal products were characterized by analytical and spectroscopic techniques, and by X-ray diffraction in a number of cases.

\section{Results and Discussion}

The reaction of $\mathrm{NbCl}_{5}$ with a two-fold excess of benzophenone imine, in dichloromethane at room temperature, led to the isolation in $55 \%$ yield of the salt $\left[\mathrm{Ph}_{2} \mathrm{C}=\mathrm{NH}_{2}\right]\left[\mathrm{NbCl}_{5}\left(\mathrm{~N}=\mathrm{CPh}_{2}\right)\right], \mathbf{1}$, that was characterized by analytical and spectroscopic methods, and X-ray diffraction (Scheme 1). Compound 1 was obtained, although with minor yield, also by using an imine/ $\mathrm{Nb}$ 1:1 molar ratio.

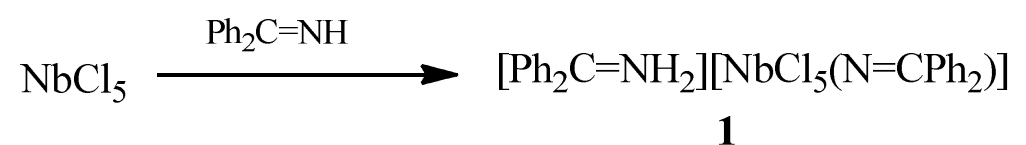

Scheme 1. The reaction of $\mathrm{NbCl}_{5}$ with benzophenone imine. 
Crystals suitable for X-ray analysis were collected from a $\mathrm{CH}_{2} \mathrm{Cl}_{2} /$ hexane mixture maintained at $-30{ }^{\circ} \mathrm{C}$. The molecular structure of 1 (Figure 1 and Table 1) consists of ionic packings of $\left[\mathrm{Ph}_{2} \mathrm{C}=\mathrm{NH}_{2}\right]^{+}$cations and $\left[\mathrm{NbCl}_{5}\left(\mathrm{~N}=\mathrm{CPh}_{2}\right)\right]^{-}$anions, the iminium $\mathrm{N}$-protons being involved in $\mathrm{H}$ bonds with the halide ligands of the anion (Table 4). The benzophenone iminium cation was previously X-ray characterized [11], while the $\left[\mathrm{NbCl}_{5}\left(\mathrm{~N}=\mathrm{CPh}_{2}\right)\right]^{-}$anion is unprecedented. It consists of an octahedral $\mathrm{Nb}(\mathrm{V})$ centre bonded to five chlorides and one diphenylmethyleneamido ligand, and represents the first structurally characterized $\mathrm{Nb}(\mathrm{V})$ complex containing an azavinylidene (methyleneamido) ligand [12]. The C(1)-N(1) distance [1.290(4) $\AA$ ] is typical for a double bond [13] and, accordingly, $\mathrm{C}(1)$ displays a perfect $\mathrm{sp}_{2}$ hybridization [sum angles at $\mathrm{C}(1)$ $\left.360.0(5)^{\circ}\right]$. The $\mathrm{Nb}(1)-\mathrm{N}(1)$ distance $[1.862(2) \AA]$ is intermediate between a single and a double bond [5a, 14]. The $\left(\mathrm{N}=\mathrm{CPh}_{2}\right)^{-}$ligand shows a linear coordination [C(1)-N(1)-Nb(1) 176.3(2) $]$. Both linear and bent coordination modes have been observed for a terminal azavinylidene ligand with miscellaneous transition metals [15].
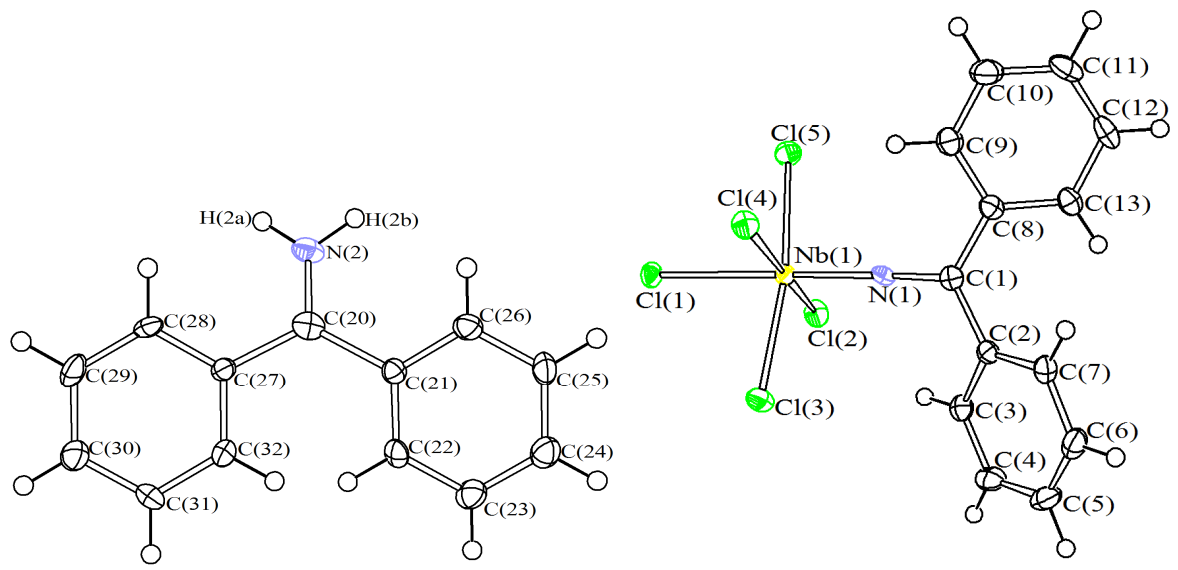

Figure 1. View of the molecular structure of $\left[\mathrm{Ph}_{2} \mathrm{C}=\mathrm{NH}_{2}\right]\left[\mathrm{NbCl}_{5}\left(\mathrm{~N}=\mathrm{CPh}_{2}\right)\right], \mathbf{1}$, with key atoms labeled. Displacement ellipsoids are at the $50 \%$ probability level.

Table 1. Selected bond lengths $(\AA)$ and angles $\left(^{\circ}\right)$ for $\mathbf{1}$

\begin{tabular}{llll}
\hline $\mathrm{Nb}(1)-\mathrm{Cl}(1)$ & $2.5258(8)$ & $\mathrm{Nb}(1)-\mathrm{Cl}(2)$ & $2.3552(9)$ \\
$\mathrm{Nb}(1)-\mathrm{Cl}(3)$ & $2.3893(9)$ & $\mathrm{Nb}(1)-\mathrm{Cl}(4)$ & $2.4143(8)$ \\
$\mathrm{Nb}(1)-\mathrm{Cl}(5)$ & $2.4005(9)$ & $\mathrm{Nb}(1)-\mathrm{N}(1)$ & $1.862(2)$ \\
$\mathrm{C}(1)-\mathrm{N}(1)$ & $1.290(4)$ & $\mathrm{C}(20)-\mathrm{N}(2)$ & $1.293(4)$
\end{tabular}




\begin{tabular}{llll}
$\mathrm{C}(1)-\mathrm{C}(2)$ & $1.474(4)$ & $\mathrm{C}(20)-\mathrm{C}(21)$ & $1.581(4)$ \\
$\mathrm{C}(1)-\mathrm{C}(8)$ & $1.472(4)$ & $\mathrm{C}(20)-\mathrm{C}(27)$ & $1.563(4)$ \\
& & & \\
$\mathrm{N}(1)-\mathrm{Nb}(1)-\mathrm{Cl}(1)$ & $175.43(8)$ & $\mathrm{Cl}(2)-\mathrm{Nb}(1)-\mathrm{Cl}(4)$ & $176.83(3)$ \\
$\mathrm{Cl}(3)-\mathrm{Nb}(1)-\mathrm{Cl}(5)$ & $170.12(3)$ & $\mathrm{Nb}(1)-\mathrm{N}(1)-\mathrm{C}(1)$ & $176.3(2)$ \\
$\mathrm{N}(1)-\mathrm{C}(1)-\mathrm{C}(2)$ & $118.1(3)$ & $\mathrm{N}(2)-\mathrm{C}(20)-\mathrm{C}(21)$ & $118.9(3)$ \\
$\mathrm{N}(1)-\mathrm{C}(1)-\mathrm{C}(8)$ & $119.5(3)$ & $\mathrm{N}(2)-\mathrm{C}(20)-\mathrm{C}(27)$ & $117.2(3)$ \\
$\mathrm{C}(2)-\mathrm{C}(1)-\mathrm{C}(8)$ & $122.4(3)$ & $\mathrm{C}(21)-\mathrm{C}(20)-\mathrm{C}(27$ & $123.9(3)$ \\
\hline
\end{tabular}

The IR spectrum of 1 (solid state) displays a broad band envelope around $1660 \mathrm{~cm}^{-1}$, probably accounting for both $[\mathrm{C}=\mathrm{N}]$ moieties. In the ${ }^{1} \mathrm{H}$ NMR spectrum $\left(\mathrm{CD}_{2} \mathrm{Cl}_{2}\right.$ solution $)$, the N-bound protons resonate at $11.4 \mathrm{ppm}$. Major ${ }^{13} \mathrm{C}$ NMR features are represented by the resonances of the iminium and azavinylidene carbons, occurring at 182.1 and $156.9 \mathrm{ppm}$, respectively. In the ${ }^{93} \mathrm{Nb}$ NMR spectrum, the presence of the $\left[\mathrm{NbCl}_{6}\right]^{-}$anion is indicated by a sharp resonance at $10.4 \mathrm{ppm}$ $[4 \mathrm{c}, 5 \mathrm{a}, 7,8]$, while the niobium nucleus belonging to the cation was not observed.

The formation of $\mathbf{1}$ appears the result of self-ionization of benzophenone imine, via intermolecular $\mathrm{H}^{+}$migration induced by the Lewis acidic $\mathrm{Nb}(\mathrm{V})$ centre. Azavinylidene ligands have been obtained from a variety of building blocks, especially ketimino derivatives LiNCRR' [12a, 16]. On the other hand, the in situ imine deprotonation has been more rarely observed. For instance, the $\left[\mathrm{M}=\mathrm{C}=\mathrm{CPh}_{2}\right]$ unit was previously in situ generated from benzophenone imine with a $\mathrm{Ti}(\mathrm{IV})$ complex [17], a $\mathrm{Ru}(\mathrm{IV})$ porphyrin complex [18] and a $\mathrm{Pd}(\mathrm{II})$ acetato complex in the presence of $\left[\mathrm{NBu}_{4}\right] \mathrm{OH}[19]$.

We moved to extend our study to the reactivity of $\mathrm{NbCl}_{5}$ with other imines. The iminium salt $\left[\mathrm{PhCH}=\mathrm{NH}^{\mathrm{t}} \mathrm{Bu}\right]\left[\mathrm{NbCl}_{6}\right], 2$, was isolated from $\mathrm{NbCl}_{5}$ and one equivalent of N-benzylidene-tertbutylamine in $52 \%$ yield, and no other products could be identified (Scheme 2). The IR spectrum of 2 clearly shows the band related to the iminium function at $1650 \mathrm{~cm}^{-1}$. Salient NMR features $\left(\mathrm{CD}_{3} \mathrm{CN}\right.$ solution $)$ are the resonances due to the $\mathrm{NH}(10.85 \mathrm{ppm})$ and iminium groups $\left({ }^{1} \mathrm{H}: 8.78\right.$ ppm; $\left.{ }^{13} \mathrm{C}: 168.1 \mathrm{ppm}\right)$. The ${ }^{93} \mathrm{Nb}$ NMR resonance of the $\left[\mathrm{NbCl}_{6}\right]^{-}$anion has been found at -0.7 
ppm. The observed variability of the chemical shift due to $\left[\mathrm{NbCl}_{6}\right]^{-}$in a restricted ppm range may be an effect of the solvent and/or the nature of the cation.

Also the 1:1 molar reaction of $\mathrm{NbCl}_{5}$ with 2,2,4,4-tetramethyl-3-pentanone imine led to the low yield isolation of a solid containing the relevant iminium cation, in admixture with non identified secondary products (Scheme 2). The iminium moiety, $\left[{ }^{\mathrm{t}} \mathrm{Bu}_{2} \mathrm{C}=\mathrm{NH}_{2}\right]^{+}[20]$, manifests itself by IR absorptions at $3380(\mathrm{~N}-\mathrm{H}), 3277(\mathrm{~N}-\mathrm{H})$ and $1639(\mathrm{C}=\mathrm{N}) \mathrm{cm}^{-1}$. The ${ }^{1} \mathrm{H}$ NMR resonance due to the two N-bound protons has been found at $9.95 \mathrm{ppm}\left(\mathrm{CD}_{3} \mathrm{CN}\right.$ solution).

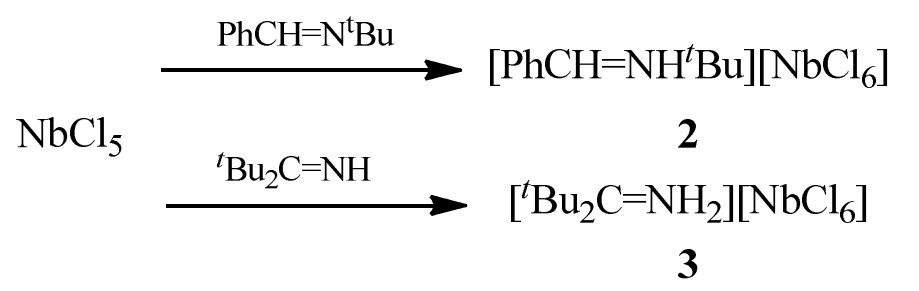

Scheme 2. Formation of iminium salts from the reactions of $\mathrm{NbCl}_{5}$ with N-benzylidene-tert-butylamine and 2,2,4,4-tetramethyl-3pentanone imine.

The formation of $\mathbf{2}$ and $\mathbf{3}$ from $\mathrm{NbCl}_{5}$ and imines is the consequence of a protonation reaction. In principle, three possible sources may contribute to the protonation, i.e. trace water, the solvent $\left(\mathrm{CH}_{2} \mathrm{Cl}_{2}\right)$ and the imine itself. In particular, it is possible that the $\mathrm{NH}$ containing imine ${ }^{\mathrm{t}} \mathrm{Bu}_{2} \mathrm{C}=\mathrm{NH}$ undergoes self protonation in the presence of $\mathrm{NbCl}_{5}$, analogously to what demonstrated for $\mathrm{Ph}_{2} \mathrm{C}=\mathrm{NH}$. We performed several experiments aimed to the identification of the possible coproducts of the proton transfer, but these did not provide conclusive results.

The 1:1 molar reactions of $\mathrm{NbF}_{5}$ with benzophenone imine and N-benzylidene-tert-butylamine afforded the hexafluoroniobate iminium salts $\left[\mathrm{Ph}_{2} \mathrm{C}=\mathrm{NH}_{2}\right]\left[\mathrm{NbF}_{6}\right], 4$, and $\left[\mathrm{PhCH}=\mathrm{NH}^{\mathrm{t}} \mathrm{Bu}\right]\left[\mathrm{NbF}_{6}\right]$, 5, respectively, in ca. 50\% yields (Scheme 3).

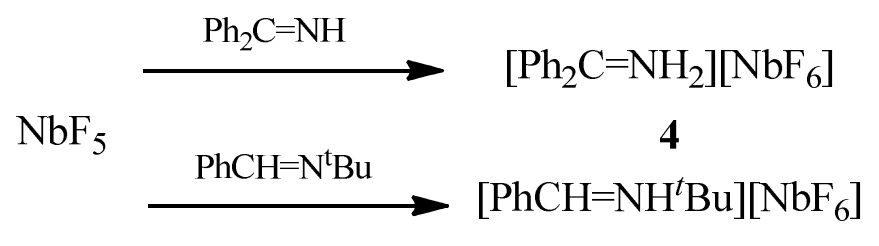


Scheme 3. Formation of iminium salts from the reactions of $\mathrm{NbF}_{5}$ with benzophenone imine and N-benzylidene-tert-butylamine.

The X-ray structure of 4 (Figure 2, Table 2) consists of ionic packings of $\left[\mathrm{Ph}_{2} \mathrm{C}=\mathrm{NH}_{2}\right]^{+}$cations and $\left[\mathrm{NbF}_{6}\right]^{-}$anions, with $\mathrm{H}$-bonds involving $\mathrm{N}$-bound hydrogens and fluoride ligands (Table 4). The $\left[\mathrm{NbF}_{6}\right]^{-}$anion displays bonding parameters resembling those previously reported in the literature $[6 \mathrm{~b}, 7 \mathrm{~b}, 21]$.

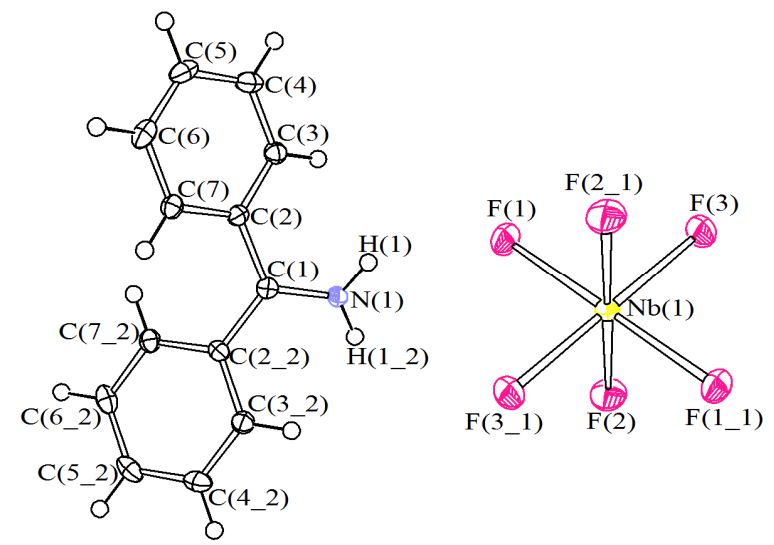

Figure 2. View of the molecular structure of $\left[\mathrm{Ph}_{2} \mathrm{C}=\mathrm{NH}_{2}\right]\left[\mathrm{NbF}_{6}\right], 4$, with key atoms labeled. Symmetry transformation used to generate equivalent atoms: (1) $-\mathrm{x}+3 / 2,-\mathrm{y}+1 / 2,-\mathrm{z}$; (2) $-\mathrm{x}+1, \mathrm{y},-\mathrm{z}+3 / 2$. Displacement ellipsoids are at the $50 \%$ probability level.

Table 2. Selected bond lengths $(\AA)$ and angles $\left(^{\circ}\right)$ for 4

\begin{tabular}{llll}
\hline $\mathrm{Nb}(1)-\mathrm{F}(1)$ & $1.8838(10)$ & $\mathrm{Nb}(1)-\mathrm{F}(2)$ & $1.9048(11)$ \\
$\mathrm{Nb}(1)-\mathrm{F}(3)$ & $1.8786(10)$ & $\mathrm{C}(1)-\mathrm{N}(1)$ & $1.293(3)$ \\
$\mathrm{C}(1)-\mathrm{C}(2)$ & $1.468(2)$ & & \\
& & & \\
$\mathrm{F}(1)-\mathrm{Nb}(1)-\mathrm{F}\left(1 \_1\right)$ & $180.00(6)$ & $\mathrm{F}(2)-\mathrm{Nb}(1)-\mathrm{F}\left(2 \_1\right)$ & $180.00(7)$ \\
$\mathrm{F}(3)-\mathrm{Nb}(1)-\mathrm{F}\left(3 \_1\right)$ & $180.00(5)$ & $\mathrm{N}(1)-\mathrm{C}(1)-\mathrm{C}(2)$ & $119.08(10)$ \\
$\mathrm{C}(2)-\mathrm{C}(1)-\mathrm{C}\left(2 \_2\right)$ & $121.8(2)$ & $\mathrm{N}(1)-\mathrm{C}(1)-\mathrm{C}\left(2 \_2\right)$ & $119.08(10)$ \\
\hline
\end{tabular}

Symmetry transformation used to generate equivalent atoms: (1) $-\mathrm{x}+3 / 2$, $-\mathrm{y}+1 / 2,-\mathrm{z} ;(2)-\mathrm{x}+1, \mathrm{y},-\mathrm{z}+3 / 2$.

The IR and NMR features related to the iminium cations within $\mathbf{4}$ and $\mathbf{5}$ resemble those already discussed for the analogous $\left[\mathrm{NbC}_{6}\right]^{-}$salts, $\mathbf{1}$ and $\mathbf{2}$. The $\left[\mathrm{NbF}_{6}\right]^{-}$anion has been characterized by means of NMR spectroscopy. Indeed this species gives raise to typical ${ }^{19} \mathrm{~F}$ and ${ }^{93} \mathrm{Nb}$ resonances, falling at ca. 104 ppm and -1550 ppm, respectively [4c, 5a,c, 6a-c, 7].

Consideration analogous to those discussed for $\mathbf{2}$ and $\mathbf{3}$ are still valid here in order to explain the 
formation of the iminium cations contained in $\mathbf{4}$ and 5. In addition, two points should be considered. First, the high stability of the $\left[\mathrm{NbF}_{6}\right]^{-}$anion is an important factor which often forces the formation of ionic species from the interaction of $\mathrm{NbF}_{5}$ with organic compounds [4c, 5c, 6a-c]. Second, 4 and 5 were isolated by precipitation from a $\mathrm{CH}_{2} \mathrm{Cl}_{2} /$ hexane mixture, and magnetic analysis of the solid residue recovered from the liquid phase evidenced the presence of paramagnetic species (the solid residues recovered from $\mathrm{NbCl}_{5} /$ imines, see above, revealed to be diamagnetic). Moreover, hydrolysis [22] of the paramagnetic substrate obtained from $\mathrm{NbF}_{5} / \mathrm{PhCH}=\mathrm{N}^{\mathrm{t}} \mathrm{Bu}$ gave a solution whose NMR analysis indicated the presence of moderate amounts of benzonitrile. The formation of $\mathrm{PhC} \equiv \mathrm{N}$ from $\mathrm{PhCH}=\mathrm{N}^{\mathrm{t}} \mathrm{Bu}$ indicates the occurrence of $\mathrm{C}-\mathrm{H}$ bond activation to some extent, possibly contributing to the main protonation reaction leading to $\mathbf{5}$.

Finally, we included a tantalum pentahalide, i.e. $\mathrm{TaCl}_{5}$, in the present study. The reaction of $\mathrm{TaCl}_{5}$ with benzophenone imine was less selective than the analogous one involving $\mathrm{NbCl}_{5}$, and afforded a complicated mixture of products. After many attempts, few crystals of the salt $\left[\mathrm{Ph}_{2} \mathrm{C}=\mathrm{NH}_{2}\right]_{2}\left[\mathrm{Ta}_{2} \mathrm{Cl}_{10} \mathrm{O}\right], \mathbf{6}$, were collected. The presence of oxygen in the anion is unambiguous evidence of the action of fortuitous water. The X-ray structure of 6 (Figure 3, Tables 3 and 4) is an ionic packing of $\left[\mathrm{Ph}_{2} \mathrm{C}=\mathrm{NH}_{2}\right]^{+}$and $\left[\mathrm{Ta}_{2} \mathrm{Cl}_{10} \mathrm{O}\right]^{2-}$ ions. The $\left[\mathrm{Ta}_{2} \mathrm{Cl}{ }_{10} \mathrm{O}\right]^{2-}$ anion was crystallographically characterized in the past, the anion displaying bonding parameters very close to those found in the present case [23].
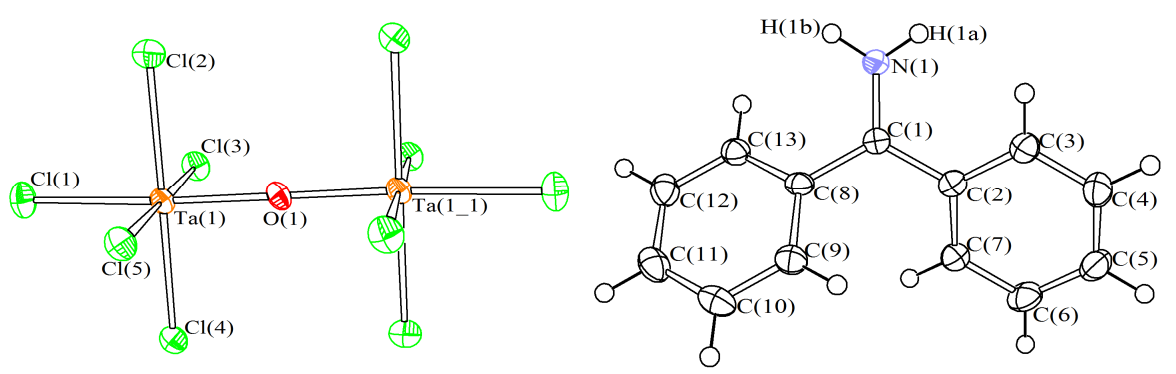

Figure 3. View of the molecular structure of $\left[\mathrm{Ph}_{2} \mathrm{C}=\mathrm{NH}_{2}\right]_{2}\left[\mathrm{Ta}_{2} \mathrm{Cl}_{10} \mathrm{O}\right]$, 6, with key atoms labeled. Symmetry transformation used to generate equivalent atoms: (1) $\mathrm{x}+2,-\mathrm{y}+\mathrm{a},-\mathrm{z}+1$. Displacement ellipsoids are at the $50 \%$ probability level.

Table 3. Selected bond lengths $(\AA)$ and angles $\left(^{\circ}\right)$ for $\mathbf{6}$ 


$\begin{array}{llll}\mathrm{Ta}(1)-\mathrm{Cl}(1) & 2.3669(11) & \mathrm{Ta}(1)-\mathrm{Cl}(2) & 2.3635(11) \\ \mathrm{Ta}(1)-\mathrm{Cl}(3) & 2.3665(11) & \mathrm{Ta}(1)-\mathrm{Cl}(4) & 2.3632(11) \\ \mathrm{Ta}(1)-\mathrm{Cl}(5) & 2.3554(10) & \mathrm{Ta}(1)-\mathrm{O}(1) & 1.8929(2) \\ \mathrm{C}(1)-\mathrm{N}(1) & 1.304(6) & \mathrm{C}(1)-\mathrm{C}(2) & 1.461(6) \\ \mathrm{C}(1)-\mathrm{C}(8) & 1.469(6) & & \\ & & & \\ \mathrm{Cl}(1)-\mathrm{Ta}(1)-\mathrm{O}(1) & 176.55(3) & \mathrm{Cl}(2)-\mathrm{Ta}(1)-\mathrm{Cl}(4) & 179.35(4) \\ \mathrm{Cl}(3)-\mathrm{Ta}(1)-\mathrm{Cl}(5) & 179.67(4) & \mathrm{Ta}(1)-\mathrm{O}(1)-\mathrm{Ta}(1-1) 180.000(5) \\ \mathrm{N}(1)-\mathrm{C}(1)-\mathrm{C}(2) & 119.5(4) & \mathrm{N}(1)-\mathrm{C}(1)-\mathrm{C}(8) & 118.6(4) \\ \mathrm{C}(2)-\mathrm{C}(1)-\mathrm{C}(8) & 121.9(4) & & \end{array}$

Symmetry transformation used to generate equivalent atoms: (1) $\mathrm{x}+2,-\mathrm{y}+\mathrm{a},-\mathrm{z}+1$.

Table 4. H-bond parameters for 1, 4 and 6.

\begin{tabular}{cllll}
\hline $\mathbf{1}$ & $\mathbf{d}(\mathbf{D}-\mathbf{H})$ & $\mathbf{d}(\mathbf{H} \cdots \mathbf{A})$ & $\mathbf{d}(\mathbf{D} \cdots \mathbf{A})$ & $<(\mathbf{D H A})$ \\
\hline $\mathrm{N}(2)-\mathrm{H}(2 \mathrm{~A}) \cdots \mathrm{Cl}(1) \# 1$ & $0.941(10)$ & $2.375(16)$ & $3.268(3)$ & $158(3)$ \\
$\mathrm{N}(2)-\mathrm{H}(2 \mathrm{~B}) \cdots \mathrm{Cl}(1) \# 2$ & $0.938(10)$ & $2.70(2)$ & $3.453(3)$ & $138(3)$ \\
$\mathrm{N}(2)-\mathrm{H}(2 \mathrm{~B}) \cdots \mathrm{Cl}(4) \# 1$ & $0.938(10)$ & $2.89(3)$ & $3.405(3)$ & $116(2)$ \\
\hline $\mathbf{3}$ & & & & \\
$\mathrm{N}(1)-\mathrm{H}(1) \ldots \mathrm{F}(2) \# 3$ & $0.868(15)$ & $2.004(15)$ & $2.8606(16)$ & $169(2)$ \\
\hline $\mathbf{4}$ & & & & \\
$\mathrm{N}(1)-\mathrm{H}(1 \mathrm{~A}) \ldots \mathrm{Cl}(4) \# 4$ & $0.878(10)$ & $2.55(3)$ & $3.311(4)$ & $145(4)$ \\
$\mathrm{N}(1)-\mathrm{H}(1 \mathrm{~B}) \ldots \mathrm{Cl}(3) \# 5$ & $0.876(10)$ & $2.88(3)$ & $3.676(4)$ & $152(4)$ \\
\hline $\mathrm{Symmetry} t r a n s f o r m a t i o n$
\end{tabular}

Symmetry transformations used to generate equivalent atoms: $\# 1-\mathrm{x}+1,-\mathrm{y}+1,-\mathrm{z}+1 ; \# 2$ $\mathrm{x}, \mathrm{y}-1, \mathrm{z} ; \# 3 \mathrm{x}-1 / 2,-\mathrm{y}+1 / 2, \mathrm{z}+1 / 2 ; \# 4 \mathrm{x}-1, \mathrm{y}, \mathrm{z} ; \# 5-\mathrm{x}+1,-\mathrm{y}+1,-\mathrm{z}+1$.

\section{Conclusions}

In the framework of our interest in the coordination chemistry of high valent metal halides, we have reported on the reactivity of niobium (tantalum) pentahalides with imines, which has not been explored up to now. In general, the reactions are scarcely selective and lead to the isolation of iminium salts, favored by the basicity of the imine moiety and the stability of $\left[\mathrm{MX}_{6}\right]^{-}$anions. Possible sources of protonation are represented by the solvent (dichloromethane), trace water and the activation of the imine reactant. In particular, the occurrence of benzophenone imine self protonation has been unambiguously observed in the reaction with $\mathrm{NbCl}_{5}$, resulting in the first crystallographic characterization of a $\mathrm{Nb}(\mathrm{V})$ azavinylidene species. Redox processes appear to be operative in the reactions involving $\mathrm{NbF}_{5}$, presumably triggered by the strong oxidative power of niobium pentafluoride $[4 b]$.

\section{Experimental}


4.1. General considerations. Air/moisture sensitive compounds were manipulated under atmosphere of pre-purified argon using standard Schlenk techniques. The reaction vessels were oven dried at $140^{\circ} \mathrm{C}$ prior to use, evacuated $\left(10^{-2} \mathrm{mmHg}\right)$ and then filled with argon. $\mathrm{NbCl}_{5}$ (99+\%), $\mathrm{NbF}_{5}(99.5+\%)$, and $\mathrm{TaCl}_{5}(99.9 \%)$ were purchased from Strem, then sublimed and stored in sealed tubes under argon. Once isolated, the metal products were conserved in sealed glass tubes under argon. Solvents (Sigma-Aldrich) were distilled from $\mathrm{P}_{4} \mathrm{O}_{10}$ before use. Imines (TCI Europe), $\mathrm{CD}_{2} \mathrm{Cl}_{2}$ and $\mathrm{CD}_{3} \mathrm{CN}$ (Cortecnet) were commercial chemicals stored under argon atmosphere as received. Infrared spectra were recorded at $298 \mathrm{~K}$ on a FT IR-Perkin Elmer Spectrometer, equipped with UATR sampling accessory. Magnetic susceptibilities were measured at $298 \mathrm{~K}$ on solid samples with a Magway MSB Mk1 magnetic susceptibility balance (Sherwood Scientific Ltd.) [24]. ${ }^{1} \mathrm{H},{ }^{13} \mathrm{C}$ NMR and ${ }^{93} \mathrm{Nb}$ NMR spectra were recorded on a Bruker Avance DRX400 instrument equipped with a BBFO broadband probe. ${ }^{1} \mathrm{H}$ and ${ }^{13} \mathrm{C}$ NMR assignments were assisted by DEPT, HSQC and HMBC experiments [25]. ${ }^{19} \mathrm{~F}$ NMR spectra were recorded on a Varian Gemini 200BB instrument. All NMR experiments were performed at $298 \mathrm{~K}$. The chemical shifts for ${ }^{1} \mathrm{H}$ and ${ }^{13} \mathrm{C}$ were referenced to the non-deuterated aliquot of the solvent; the chemical shifts for ${ }^{19} \mathrm{~F}$ were referenced to external $\mathrm{CFCl}_{3}$; the chemical shifts for ${ }^{93} \mathrm{Nb}$ were referenced to external $\left[\mathrm{NEt}_{4}\right]\left[\mathrm{NbCl}_{6}\right]$. Carbon, hydrogen and nitrogen analyses were performed on Carlo Erba mod. 1106 instrument. The chloride content was determined by the Mohr method [26] on solutions prepared by dissolution of the solid in aqueous $\mathrm{KOH}$ at boiling temperature, followed by cooling to room temperature and addition of $\mathrm{HNO}_{3}$ up to neutralization. The metal was analyzed as $\mathrm{M}_{2} \mathrm{O}_{5}$ obtained by high temperature treatment of the solid sample with $\mathrm{HNO}_{3}$ solution, followed by calcination in a platinum crucible.

\subsection{Reactions of $\mathrm{NbCl}_{5}$ with imines.}


4.2.1. Synthesis of $\left[\mathrm{Ph}_{2} \mathrm{C}=\mathrm{NH}_{2}\right]\left[\mathrm{NbCl}_{5}\left(\mathrm{~N}=\mathrm{CPh} h_{2}\right)\right]$, 1. A suspension of $\mathrm{NbCl}_{5}(0.250 \mathrm{~g}, 0.925$ mmol) in $\mathrm{CH}_{2} \mathrm{Cl}_{2}(15 \mathrm{~mL})$ was treated with benzophenone imine $(0.320 \mathrm{~mL}, 1.91 \mathrm{mmol})$. The mixture was stirred at room temperature for $18 \mathrm{~h}$, and the resulting dark-brown mixture was filtered in order to remove some insoluble material. Then the filtered solution was concentrated up to ca. $5 \mathrm{~mL}$, layered with pentane and stored at $-30{ }^{\circ} \mathrm{C}$. Compound $\mathbf{1}$ was isolated as a greenishbrown solid after $72 \mathrm{~h}$. Yield $0.322 \mathrm{~g}, 55 \%$. Crystals suitable for X-ray analysis were collected from a $\mathrm{CH}_{2} \mathrm{Cl}_{2}$ solution layered with hexane and stored at $-30{ }^{\circ} \mathrm{C}$ for one week. Anal. Calcd. for $\mathrm{C}_{26} \mathrm{H}_{22} \mathrm{Cl}_{5} \mathrm{~N}_{2} \mathrm{Nb}$ : C, 49.36; H, 3.51; N, 4.43; Cl, 28.02; Nb, 14.69. Found: C, 49.45; H, 3.37; N, 4.36; Cl, 27.87; Nb, 14.39. IR (solid state): 3334w, 3267w, 3206w, 3066w, $1675 \mathrm{~m}-\mathrm{sh}\left(v_{\mathrm{C}=\mathrm{N}}\right)$, $1652 \mathrm{~s}\left(\mathrm{v}_{\mathrm{C}=\mathrm{N}}\right), 1591 \mathrm{~s}-\mathrm{sh}, 1583 \mathrm{~s}, 1571 \mathrm{~m}-\mathrm{sh}, 1488 \mathrm{~m}, 1462 \mathrm{vs}, 1453 \mathrm{vs}-\mathrm{sh}, 1406 \mathrm{vs}, 1472 \mathrm{vs}, 1328 \mathrm{~s}$, 1292s, 1179m, 1164m-s, 1102w-m, 1026w, 995m, 938w, 822vs, 795s, 777m, 737s, 690s, 665s $\mathrm{cm}^{-1} .{ }^{1} \mathrm{H}$ NMR $\left(\mathrm{CD}_{2} \mathrm{Cl}_{2}\right): \delta=11.4(\mathrm{br}, 2 \mathrm{H}, \mathrm{NH}), 8.15,7.92,7.74,7.67(\mathrm{~m}, 20 \mathrm{H}, \mathrm{Ph}) \mathrm{ppm} .{ }^{13} \mathrm{C}$ NMR $\left(\mathrm{CD}_{2} \mathrm{Cl}_{2}\right): \delta=182.1\left(\mathrm{CNH}_{2}\right), 156.9(\mathrm{CNNb}), 138.1,136.4,134.9,134.4,132.4,131.6$, $130.5,129.6,129.0,127.1(\mathrm{Ph}) \mathrm{ppm} .{ }^{93} \mathrm{Nb}\left(\mathrm{CD}_{2} \mathrm{Cl}_{2}\right): \delta=10.4\left(\mathrm{~s}, \Delta v^{1 / 2}=1.3 \times 10 \mathrm{~Hz}\right) \mathrm{ppm}$.

4.2.2. Synthesis of $\left[\mathrm{PhCH}=\mathrm{NH}^{t} \mathrm{Bu}\right]\left[\mathrm{NbCl}_{6}\right], 2$ and $\left[{ }^{t} \mathrm{Bu} u_{2} \mathrm{C}=\mathrm{NH}_{2}\right]\left[\mathrm{NbCl}_{6}\right]$, 3. Only the preparation of $\mathbf{2}$ is described in detail, $\mathbf{3}$ being obtained in a similar way. N-benzylidene-tert-butylamine $(0.135 \mathrm{~mL}, 0.759 \mathrm{mmol})$ was added to a suspension of $\mathrm{NbCl}_{5}(0.200 \mathrm{~g}, 0.740 \mathrm{mmol})$ in $\mathrm{CH}_{2} \mathrm{Cl}_{2}$ $(15 \mathrm{~mL})$. The mixture was allowed to react at room temperature for $18 \mathrm{~h}$. The final mixture was treated with hexane $(30 \mathrm{~mL})$, and the abundant brown precipitate was separated and then dried in vacuo. Yield $0.185 \mathrm{~g}, 52 \%$ (with reference to the organic reactant). Anal. Calcd. for $\mathrm{C}_{11} \mathrm{H}_{16} \mathrm{Cl}_{6} \mathrm{NNb}: \mathrm{C}, 28.24 ; \mathrm{H}, 3.45 ; \mathrm{N}, 2.99 ; \mathrm{Cl}, 45.46 ; \mathrm{Nb}, 19.86$. Found: $\mathrm{C}, 28.07 ; \mathrm{H}, 3.38 ; \mathrm{N}$, 3.06; Cl, 45.22; Nb, 19.97. IR (solid state): 3306w, 3256w, 3058w, 2978w, 1650s $\left(v_{\mathrm{C}=\mathrm{N}}\right), 1594 \mathrm{~s}$, $1455 \mathrm{w}, 1413 \mathrm{w}, 1382 \mathrm{w}, 1328 \mathrm{w}, 1310 \mathrm{w}, 1262 \mathrm{w}, 1237 \mathrm{~m}, 1185 \mathrm{~s}, 1023 \mathrm{~s}, 896 \mathrm{w}, 821 \mathrm{~m}, 744 \mathrm{vs}, 694 \mathrm{~m}$, $673 \mathrm{vs} \mathrm{cm}^{-1} .{ }^{1} \mathrm{H}$ NMR $\left(\mathrm{CD}_{3} \mathrm{CN}\right): \delta=10.85(\mathrm{~s}, 1 \mathrm{H}, \mathrm{NH}), 8.78(\mathrm{~s}, 1 \mathrm{H}, \mathrm{CH}), 8.10,7.88,7.73(\mathrm{~m}, 5$ 
$\mathrm{H}, \mathrm{Ph}), 1.61\left(\mathrm{~s}, 9 \mathrm{H}, \mathrm{CMe} e_{3}\right)$ ppm. ${ }^{13} \mathrm{C} \mathrm{NMR}\left(\mathrm{CD}_{3} \mathrm{CN}\right): \delta=168.1(\mathrm{C}=\mathrm{N}), 137.7,132.5,130.2(\mathrm{Ph})$, 127.0 (ipso-Ph), $62.4\left(\mathrm{CMe}_{3}\right), 27.5\left(\mathrm{CMe}_{3}\right)$ ppm. ${ }^{93} \mathrm{Nb}\left(\mathrm{CD}_{3} \mathrm{CN}\right): \delta=-0.7\left(\mathrm{~s}, \Delta v^{1 / 2}=1 \times 10^{2} \mathrm{~Hz}\right)$ ppm.

$\left[{ }^{t} \mathrm{Bu}_{2} \mathrm{C}=\mathrm{NH}_{2}\right]\left[\mathrm{NbCl}_{6}\right]$, 3. light-yellow solid, $47 \%$ yield from $\mathrm{NbCl}_{5}(0.320 \mathrm{~g}, 1.18 \mathrm{mmol})$ and ${ }^{\mathrm{t}} \mathrm{Bu}_{2} \mathrm{C}=\mathrm{NH}(1.20 \mathrm{mmol})$. Anal. Calcd. for $\mathrm{C}_{11} \mathrm{H}_{16} \mathrm{Cl}_{6} \mathrm{NNb}$ : C, 24.13; H, 4.50; N, 3.13; Cl, 47.49; Nb, 20.74. Found: C, 24.09; H, 4.38; N, 3.03; Cl, 47.72; Nb, 20.01. IR (solid state): 3380w ( $\left.\mathrm{v}_{\mathrm{N}-\mathrm{H}}\right)$, $3277 \mathrm{w}\left(v_{\mathrm{N}-\mathrm{H}}\right), 1639 \mathrm{~m}\left(v_{\mathrm{C}=\mathrm{N}}\right) \mathrm{cm}^{-1} .{ }^{1} \mathrm{H}$ NMR $\left(\mathrm{CD}_{3} \mathrm{CN}\right): \delta=9.95\left(\mathrm{~s}, \mathrm{NH}_{2}\right) ; 1.65\left(\mathrm{~s}, 18 \mathrm{H},{ }^{\mathrm{t}} \mathrm{Bu}\right) \mathrm{ppm}$.

\subsection{Reactions of $\mathrm{NbF}_{5}$ with imines.}

4.3.1. Synthesis of $\left[\mathrm{Ph}_{2} \mathrm{C}=\mathrm{NH}_{2}\right]\left[\mathrm{NbF}_{6}\right]$, 4. A mixture of $\mathrm{NbF}_{5}(0.150 \mathrm{~g}, 0.798 \mathrm{mmol}), \mathrm{CH}_{2} \mathrm{Cl}_{2}(20$ $\mathrm{mL})$ and benzophenone imine $(0.135 \mathrm{~mL}, 0.806 \mathrm{mmol})$ was allowed to react for $18 \mathrm{~h}$ at room temperature. The resulting solution was treated with hexane $(30 \mathrm{~mL})$, and the resulting red solid was isolated and dried in vacuo. Yield $0.151 \mathrm{~g}, 48 \%$ (respect to the organic reactant). Crystals suitable for X-ray analysis were collected from a $\mathrm{CH}_{2} \mathrm{Cl}_{2} /$ hexane mixture stored at $-30 \mathrm{C}$ for one week. Anal. Calcd. for $\mathrm{C}_{13} \mathrm{H}_{12} \mathrm{~F}_{6} \mathrm{NNb}$ : C, 40.12; H, 3.11; N, 3.60; F, 29.29; Nb, 23.87. Found: C, 40.22; H, 3.02; N, 3.65; F, 29.58; Nb, 23.76. IR (solid state): 3260w, 3195w $\left(v_{\mathrm{N}-\mathrm{H}}\right), 3059 \mathrm{w}-\mathrm{m}$, $1970 \mathrm{vw}, 1669 \mathrm{~m}\left(v_{\mathrm{C}=\mathrm{N}}\right), 1596 \mathrm{~s}\left(\mathrm{v}_{\mathrm{C}=\mathrm{C}}, \mathrm{Ph}\right), 1567 \mathrm{~m}-\mathrm{s}, 1489 \mathrm{w}, 1447 \mathrm{~s}, 1372 \mathrm{~s}, 1299 \mathrm{w}, 1274 \mathrm{w}-\mathrm{m}$, 1192w-m, 1162m, 1074w-m, 1028w-m, 999w-m, 932m, 884s, 790s, 763m-s, 726m, 693vs cm ${ }^{-1}$. ${ }^{1} \mathrm{H} \mathrm{NMR}\left(\mathrm{CDCl}_{3}\right): \delta=10.54\left(\mathrm{~s}, 2 \mathrm{H}, \mathrm{NH}_{2}\right) ; 7.71-7.41(\mathrm{~m}, 10 \mathrm{H}, \mathrm{Ph}) \mathrm{ppm} .{ }^{13} \mathrm{C} \mathrm{NMR}\left(\mathrm{CDCl}_{3}\right): \delta=$ $180.3(\mathrm{C}=\mathrm{N}) ; 136.4\left(\right.$ ipso-Ph), 132.2, $129.5,128.7(\mathrm{Ph}) \mathrm{ppm} .{ }^{19} \mathrm{~F}\left(\mathrm{CDCl}_{3}\right): \delta=103.5\left(\mathrm{~m},\left[\mathrm{NbF}_{6}\right]^{-}\right)$ ppm. ${ }^{93} \mathrm{Nb} \mathrm{NMR}\left(\mathrm{CDCl}_{3}\right): \delta=-1549\left(\mathrm{~m},\left[\mathrm{NbF}_{6}\right]^{-}\right) \mathrm{ppm}$.

4.3.2. Synthesis of $\left[P h C H=N H^{t} B u\right]\left[N b F_{6}\right]$, 5. The reaction of N-benzylidene-tert-butylamine $(0.160 \mathrm{~mL}, 0.900 \mathrm{mmol})$ with $\mathrm{NbF}_{5}(0.160 \mathrm{~g}, 0.852 \mathrm{mmol})$ was carried out by a procedure similar to that described for $\mathrm{NbF}_{5} / \mathrm{Ph}_{2} \mathrm{C}=\mathrm{NH}$. Yield $0.170 \mathrm{~g}, 54 \%$. Anal. Calcd. for $\mathrm{C}_{11} \mathrm{H}_{16} \mathrm{~F}_{6} \mathrm{NNb}$ : $\mathrm{C}$, 
35.79; H, 4.37; N, 3.79; F, 30.88; Nb, 25.17. Found: C, 35.22; H, 4.60; N, 3.65; F, 30.41; Nb, 25.00. IR (solid state): 3277vw (NH), 2988vw, 1657m $(\mathrm{C}=\mathrm{N}), 1598 \mathrm{~m}, 1458 \mathrm{w}, 1424 \mathrm{vw}, 1386 \mathrm{w}$,

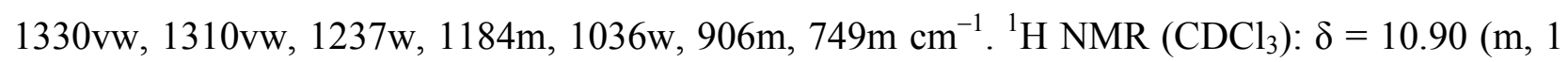
$\mathrm{H}, \mathrm{NH}) ; 8.80(\mathrm{~d}, 1 \mathrm{H}, \mathrm{CH}=\mathrm{N}) ; 8.08,7.90,7.72(\mathrm{~m}, 5 \mathrm{H}, \mathrm{Ph}) ; 1.60\left(\mathrm{~s}, 9 \mathrm{H},{ }^{\mathrm{t}} \mathrm{Bu}\right) \mathrm{ppm} .{ }^{13} \mathrm{C} \mathrm{NMR}$ $\left(\mathrm{CDCl}_{3}\right): \delta=167.9(\mathrm{C}=\mathrm{N}) ; 137.6,131.0,126.8($ arom $\mathrm{CH}) ; 126.8\left(\right.$ ipso-Ph); $62.4\left(C \mathrm{Me}_{3}\right) ; 26.9$ $\left(\mathrm{CMe}_{3}\right)$ ppm. ${ }^{19} \mathrm{~F}\left(\mathrm{CDCl}_{3}\right): \delta=103.6\left(\mathrm{~m},\left[\mathrm{NbF}_{6}\right]^{-}\right) \mathrm{ppm} .{ }^{93} \mathrm{Nb} \mathrm{NMR}\left(\mathrm{CDCl}_{3}\right): \delta=-1550(\mathrm{~m}$, $\left.\left[\mathrm{NbF}_{6}\right]^{-}\right) \mathrm{ppm}$.

The $\mathrm{CH}_{2} \mathrm{Cl}_{2} /$ hexane liquors obtained from the reactions of $\mathrm{NbF}_{5}$ with imines were separated and then eliminated of the volatile materials in vacuo. Magnetic analyses on the resulting solid residues were as follows. From $\mathrm{NbF}_{5} / \mathrm{Ph}_{2} \mathrm{C}=\mathrm{NH}: \chi_{\mathrm{M}}{ }^{\text {corr }}=1.02 \times 10^{-3}$ cgsu. From $\mathrm{NbF}_{5} / \mathrm{PhCH}=\mathrm{N}^{t} \mathrm{Bu}: \chi_{\mathrm{M}}{ }^{\text {corr }}=5.63 \times 10^{-4}$ cgsu. The solid obtained from $\mathrm{NbF}_{5} / \mathrm{PhCH}=\mathrm{N}^{\dagger} \mathrm{Bu}$ was treated with $\mathrm{CDCl}_{3}(1.5 \mathrm{~mL})$ and $\mathrm{H}_{2} \mathrm{O}(0.2 \mathrm{~mL})$. The mixture was stirred in contact with air for 48 h. Subsequent NMR analysis on the organic phase allowed to detect some $\mathrm{PhC} \equiv \mathrm{N}$.

4.4. Synthesis of $\left[\mathrm{Ph}_{2} \mathrm{C}=\mathrm{NH}_{2}\right]_{2}\left[\mathrm{Ta}_{2} \mathrm{Cl} l_{10} \mathrm{O}\right]$, 6. The reaction of $\mathrm{TaCl}_{5}(0.340 \mathrm{~g}, 0.949 \mathrm{mmol})$ with benzophenone imine $(0.160 \mathrm{~mL}, 0.955 \mathrm{mmol})$ was carried out by using a procedure similar to that described for $\mathrm{NbCl}_{5} / \mathrm{Ph}_{2} \mathrm{C}=\mathrm{NH}$. Crystals of $6 \cdot 2 \mathrm{CH}_{2} \mathrm{Cl}_{2}$ were collected after several attempts by settling aside an orange reaction mixture, layered with hexane, at $-30{ }^{\circ} \mathrm{C}$ for one week. Yield $0.031 \mathrm{~g}, 5 \%$ (with reference to the organic reactant). Anal. Calcd. for $\mathrm{C}_{28} \mathrm{H}_{28} \mathrm{Cl}_{14} \mathrm{~N}_{2} \mathrm{OTa}$ : $\mathrm{C}, 26.55$; H, 2.23; N, 2.21; Cl, 39.18; Ta, 28.57. Found: C, 26.33; H, 2.15; N, 2.31; Cl, 39.02; Ta, 28.38. IR (solid state): 3381w, 3333w, 3252w, 1659s $\left(v_{\mathrm{C}=\mathrm{N}}\right), 1592 \mathrm{~s}, 1515 \mathrm{~m}, 1488 \mathrm{~m}, 1453 \mathrm{~s}, 1375 \mathrm{~s}, 1324 \mathrm{w}$, 1299w, 1186w, 1164w, 1128w, 1087w, 998w, 938w, 777m, 739vs, 694vs, 665s cm ${ }^{-1} .{ }^{1} \mathrm{H}$ NMR $\left(\mathrm{CD}_{2} \mathrm{Cl}_{2}\right): \delta=9.57(\mathrm{br}, 2 \mathrm{H}, \mathrm{NH}), 8.11,8.01,7.87,7.78(\mathrm{~m}, 10 \mathrm{H}, \mathrm{Ph}) \mathrm{ppm} .{ }^{13} \mathrm{C} \mathrm{NMR}\left(\mathrm{CD}_{2} \mathrm{Cl}_{2}\right): \delta$ $=184.6(\mathrm{C}=\mathrm{N}), 137.9,132.5,130.3(\mathrm{Ph}), 129.4($ ipso-Ph $) \mathrm{ppm}$. 
4.6. X-ray crystallographic studies. Crystal data and collection details for $\mathbf{1} \cdot 0.5 \mathrm{CH}_{2} \mathrm{Cl}_{2}, 4$ and $\mathbf{6} \cdot 2 \mathrm{CH}_{2} \mathrm{Cl}_{2}$ are listed in Table 5. The diffraction experiments were carried out on a Bruker APEX II diffractometer equipped with a CCD detector and using Mo-K $\alpha$ radiation. Data were corrected for Lorentz polarization and absorption effects (empirical absorption correction SADABS) [27]. Structures were solved by direct methods and refined by full-matrix least-squares based on all data using $F^{2}$ [27]. All non-hydrogen atoms were refined with anisotropic displacement parameters. Cbonded hydrogen atoms were fixed at calculated positions and refined by a riding model, whereas $\mathrm{N}$ bonded hydrogens have been located in the Fourier map and refined isotropically using the 1.2 fold $U_{\text {iso }}$ value of the parent $\mathrm{N}$-atom with restrained $\mathrm{N}-\mathrm{H}$ distances. The $\mathrm{CH}_{2} \mathrm{Cl}_{2}$ molecule of $1 \cdot 0.5 \mathrm{CH}_{2} \mathrm{Cl}_{2}$ is disordered over four positions, two by two correlated by an inversion centre. The two independent images have been refined isotropically using similar $U$ restraints [SIMU command in SHELXL; s.u. 0.005] and restrained C-Cl distances [DFIX 1.75 command in SHELXL; s.u. 0.01].

Table 5. Crystal data and details of the structure refinement for $\left[\mathrm{Ph}_{2} \mathrm{C}=\mathrm{NH}_{2}\right]\left[\mathrm{NbCl}_{5}\left(\mathrm{~N}=\mathrm{CPh}_{2}\right)\right] \cdot 0.5 \mathrm{CH}_{2} \mathrm{Cl}_{2}$, $\mathbf{1} \cdot 0.5 \mathrm{CH}_{2} \mathrm{Cl}_{2},\left[\mathrm{Ph}_{2} \mathrm{C}=\mathrm{NH}_{2}\right]\left[\mathrm{NbF}_{6}\right], \mathbf{4}$, and $\left[\mathrm{Ph}_{2} \mathrm{C}=\mathrm{NH}_{2}\right]\left[\mathrm{Ta}_{2} \mathrm{Cl}_{10} \mathrm{O}\right] \cdot 2 \mathrm{CH}_{2} \mathrm{Cl}_{2}, \mathbf{6} \cdot 2 \mathrm{CH}_{2} \mathrm{Cl}_{2}$.

\begin{tabular}{|c|c|c|c|}
\hline Complex & $\mathbf{1} \cdot 0.5 \mathrm{CH}_{2} \mathrm{Cl}_{2}$ & 4 & 6. $2 \mathrm{CH}_{2} \mathrm{Cl}_{2}$ \\
\hline Formula & $\mathrm{C}_{26.5} \mathrm{H}_{23} \mathrm{Cl}_{6} \mathrm{~N}_{2} \mathrm{Nb}$ & $\mathrm{C}_{13} \mathrm{H}_{12} \mathrm{~F}_{6} \mathrm{NNb}$ & $\mathrm{C}_{28} \mathrm{H}_{28} \mathrm{Cl}_{14} \mathrm{~N}_{2} \mathrm{OTa}_{2}$ \\
\hline$F w$ & 675.08 & 389.15 & 1266.72 \\
\hline $\mathrm{T}, \mathrm{K}$ & $100(2)$ & $100(2)$ & $100(2)$ \\
\hline$\lambda, \AA$ & 0.71073 & 0.71073 & 0.71073 \\
\hline Crystal system & Triclinic & Monoclinic & Triclinic \\
\hline Space group & $\overline{P 1}$ & $C 2 / c$ & $\overline{P 1}$ \\
\hline$a, \AA$ & $9.9964(10)$ & $10.050(2)$ & $7.9420(8)$ \\
\hline$b, \AA$ & $11.1707(12)$ & $10.166(2)$ & $10.8191(11)$ \\
\hline$c, \AA$ & $14.6301(15)$ & $13.885(3)$ & $13.3952(13)$ \\
\hline$\alpha,{ }^{\circ}$ & $71.4490(10)$ & 90 & $67.6340(10)$ \\
\hline$\beta, \stackrel{\circ}{ }$ & $87.0600(10)$ & $94.885(2)$ & $76.1120(10)$ \\
\hline$\gamma,{ }^{\circ}$ & $65.0340(10)$ & 90 & $84.4360(10)$ \\
\hline Cell Volume, $\AA^{3}$ & $1397.5(3)$ & $1413.5(6)$ & $1033.26(18)$ \\
\hline $\mathrm{Z}$ & 2 & 4 & 1 \\
\hline$D_{c}, \mathrm{~g} \mathrm{~cm}^{-3}$ & 1.604 & 1.829 & 2.036 \\
\hline$\mu, \mathrm{mm}^{-1}$ & 1.024 & 0.910 & 6.223 \\
\hline $\mathrm{F}(000)$ & 678 & 768 & 602 \\
\hline Crystal size, mm & $0.19 \times 0.16 \times 0.12$ & $0.24 \times 0.21 \times 0.15$ & $0.23 \times 0.21 \times 0.18$ \\
\hline$\theta$ limits, $^{\circ}$ & $1.48-26.00$ & $2.86-27.99$ & $1.69-27.10$ \\
\hline Reflections collected & 14538 & 6977 & 11623 \\
\hline
\end{tabular}


Independent reflections

Data / restraints / parameters

Goodness of fit on $\mathrm{F}^{2}$

$R_{1}(I>2 \sigma(I))$

$w R_{2}$ (all data)

Largest diff. peak and hole, e $\AA^{-3}$

$5470\left[R_{\text {int }}=0.0430\right]$
$5470 / 18 / 385$
1.032
0.0375
0.0789
$0.891 /-0.859$

$5470\left[R_{\text {int }}=0.0430\right]$

$1679\left[R_{\text {int }}=0.0306\right]$

$1839 / 1 / 78$

1.043

0.0212

0.0548

$0.416 /-0.574$
$4525\left[R_{\text {int }}=0.0371\right]$

4525 / 2 / 220

1.042

0.0301

0.0701

$1.765 /-1.069$

Supporting Information. CCDC contain the supplementary crystallographic data for the X-ray studies reported in this paper. CCDC $1471160\left(\mathbf{1} \cdot 0.5 \mathrm{CH}_{2} \mathrm{Cl}_{2}\right), 1471161$ (4) and 1471162 $\left(6 \cdot 2 \mathrm{CH}_{2} \mathrm{Cl}_{2}\right)$. For ESI and crystallographic data in CIF or other electronic format see DOI: XXXXXXX.

Acknowledgements. The University of Pisa is gratefully acknowledged for financial support.

\section{References}

1 The pentafluorides of niobium and tantalum have tetranuclear structure in the solid state [A. J. Edwards, J. Chem. Soc. (1964) 3714], while the pentachlorides are dinuclear in the solid state $\left[\mathrm{NbCl}_{5}\right.$ : F. A. Cotton, P. A. Kibala, M. Matusz, R. B. W. Sandor, Acta Crystallogr, Section C 47 (1991) 2435; TaCl 5 : S. Rabe, U. Müller, Z. Kristallogr. New Crystal Struct. 215 (2000) 1]. All of these compounds will be mentioned by the empirical formulas $\mathrm{MX}_{5}$ throughout this paper.

2 (a) M. Bortoluzzi, F. Marchetti, G. Pampaloni, M. Pucino, S. Zacchini, Dalton Trans. 42 (2013) 13054.

(b) F. Marchetti, C. Pinzino, S. Zacchini, G. Pampaloni, Angew. Chem. Int. Ed. 49 (2010) 5268.

3 (a) Z. Xue, Y. Zhang, G. Li, J. Wang, W. Zhao, T. Mu, Catal. Sci. Technol. 6 (2016) 1070.

(b) Y. Satoh, Y. Obora, Eur. J. Org. Chem. (2015) 5041. 
(c) S. M. Coman, M. Verziu, A. Tirsoaga, B. Jurca, C. Teodorescu, V. Kuncser, V. I. Parvulescu, G. Scholz, E. Kemnitz, ACS Catal. 5 (2015) 3013.

(d) M. E. Wilhelm, M. H. Anthofer, R. M. Reich, V. D'Elia, J.-M. Basset, W. A. Herrmann, M. Cokoja, F. E. Kühn, Catal. Sci. Technol. 4 (2014) 1638.

(e) A. Monassier, V. D'Elia, M. Cokoja, H. Dong, J. D. A. Pelletier, J.-M. Basset, F. E. Kühn, ChemCatChem 5 (2013) 1321.

(f) C. Redshaw, M. Walton, L. Clowes, D. L. Hughes, A.-M. Fuller, Y. Chao, A. Walton, V. Sumerin, P. Elo, I. Soshnikov, W. Zhao, W.-H. Sun, Chem. Eur. J. 19 (2013) 8884.

(g) K. Fuchibe, T. Kaneko, K. Mori, T. Akiyama, Angew. Chem. Int. Ed. 48 (2009) 8070.

4 (a) M. Bortoluzzi, M. Hayatifar, F. Marchetti, G. Pampaloni, S. Zacchini, Inorg. Chem. 54 (2015) 4047.

(b) F. Marchetti, G. Pampaloni, C. Pinzino, Chem. Eur. J. 19 (2013) 13962.

(c) F. Marchetti, G. Pampaloni, Chem. Commun. 48 (2012) 635, and references therein.

(d) M. Aresta, A. Dibenedetto, P. Stufano, B. M. Aresta, S. Maggi, I. Pápai, T. A. Rokob, B. Gabriele, Dalton Trans. 39 (2010) 6985.

5 (a) R. Bondi, F. Marchetti, G. Pampaloni, S. Zacchini, Polyhedron 100 (2015) 192.

(b) R. Haiges, P. Deokar, K. O. Christe, Z. Anorg. Allg. Chem. 640 (2014) 1568.

(c) S. L. Benjamin, W. Levason, G. Reid, Chem. Soc. Rev. 42 (2013) 1460.

(d) U. Jayarathne, J. T. Mague, J. P. Donahue, Polyhedron 58 (2013) 13.

6 (a) W. Levason, G. Reid, W. Zhang, J. Fluorine Chem. 172 (2015) 62.

(b) W. Levason, M. E. Light, G. Reid, W. Zhang, Dalton Trans. 43 (2014) 9557.

(c) M. Jura, W. Levason, R. Ratnani, G. Reid, M. Webster, Dalton Trans. 39 (2010) 883.

(d) D. Hoppe, D. Schemmel, M. Schütz, A. Pfitzner, Chem. Eur. J. 15 (2009) 7129. 
7 (a) M. Bortoluzzi, E. Ferretti, F. Marchetti, G. Pampaloni, S. Zacchini, Dalton Trans. (2016), DOI: $10.1039 / \mathrm{C} 6 \mathrm{DT} 00533 \mathrm{~K}$

(b) R. Bini, C. Chiappe, F. Marchetti, G. Pampaloni, S. Zacchini, Inorg Chem., 49 (2010) $339-351$

8 F. Marchetti, G. Pampaloni, S. Zacchini, RSC Adv. 4 (2014) 60878.

9 (a) M. Hayatifar, F. Marchetti, G. Pampaloni, S. Zacchini, Polyhedron 70 (2014) 6.

(b) F. Marchetti, G. Pampaloni, C. Pinzino, S. Zacchini, Eur. J. Inorg. Chem. (2013) 5755.

(c) M. Jura, W. Levason, G. Reid, M. Webster, Dalton Trans. (2009) 7610.

(d) F. Marchetti, G. Pampaloni, S. Zacchini, Dalton Trans. (2007) 4343.

10 (a) S. R. Waldvogel, S. Trosien, Chem. Commun. 48 (2012) 9109.

(b) N. G. Connelly, W. E. Geiger, Chem. Rev. 96 (1996) 877.

11 J. A. Cabeza, I. del Río, M. Suárez, S. García-Granda, Acta Cryst. E58 (2002) o429.

12 Crystallographically characterized $\mathrm{Nb}$-vinylidene complexes are:

(a) P. L. Damon, C. J. Liss, R. A. Lewis, S. Morochnik, D. E. Szpunar, J. Telser, T. W. Hayton, Inorg. Chem. 54 (2015) 10081.

(b) G. Aharonian, L. G. Hubert-Pfalzgraf, A. Zaki, G. Le Borgne, Inorg. Chem. 30 (1991) 3105

13 F. H. Allen, O. Kennard, D. G. Watson, L. Brammer, A. G. Orpen, R. Taylor J. Chem. Soc. Perkin Trans. 2 (1987) S1.

14 (a) K. C. Jayaratne, G. P. A. Yap, B. S. Haggerty, A. L. Rheingold, C. H. Winter, Inorg. Chem. 35 (1996) 4910.

(b) H. Bezler, J. Strähle, Z. Naturforsch. 34B (1979) 1199.

15 (a) M. J. Ferreira, A. M. Martins, Coord. Chem. Rev. 250 (2006) 118.

(b) J.-S. Huang, S. K.-Y. Leung, K.-K. Cheung, C.-M. Che, Chem. Eur. J. 6 (2000) 2971. 
(c) F. A. Cotton, G. Wilkinson, Advanced Inorganic Chemistry, 5th ed., Wiley, New York (1988) 371.

(d) B. F. G. Johnson, B. L. Haymore, J. R. Dilworth in Comprehensive Coordination Chemistry, Vol. 2 (Eds.: G. Wilkinson, R. D. Gillard, J. A. McCleverty), Pergamon Press, Oxford (1987) 99.

16 (a) K. Nomura, J. Yamada, W. Wang, J. Liu, J. Organomet. Chem. 692 (2007) 4675.

(b) K. C. Jantunen, C. J. Burns, I. Castro-Rodriguez, R. E. Da Re, J. T. Golden, D. E. Morris,

B. L. Scott, F. L. Taw, J. L. Kiplinger, Organometallics 23 (2004) 4682.

(c) E. Hevia, J. Pérez, V. Riera, D. Miguel, Angew. Chem. Int. Ed. 41 (2002) 3858.

(d) H. Werner, W. Knaup, M. Dzialias, Angew. Chem. Int. Ed. 26 (1987) 248.

17 T. Janssen, R. Severin, M. Diekmann, M. Friedemann, D. Haase, W. Saak, S. Doye, R. Beckhaus, Organometallics 29 (2010) 1806.

18 J.-S. Huang, S. K.-Y. Leung, Z.-Y. Zhou, N. Zhu, C.-M. Che, Inorg. Chem. 44 (2005) 3780.

19 J. Ruiz, V. Rodrìguez, N. Cutillas, A. Hoffmann, A.-C. Chamayou, K. Kazmierczak, C. Janiak, CrystEngComm., 10 (2008) 1928.

20 B. Samuel, R. Snaith, C. Summerford, K. Wade, J. Chem. Soc. A (1970) 2019.

21 (a) R. Haiges, P. Deokar, K. O. Christe, Z. Anorg. Allg. Chem. 640 (2014) 1568.

(b) F. Xu, K. Matsumoto, R. Hagiwara, Dalton Trans. 41 (2012) 3494.

22 The hydrolysis of the reaction mixtures facilitates the release of the organic material from the highly oxophilic metal species, and allows the spectroscopic identification of the former. This strategy has been successfully adopted by ourselves in previous works, having proved that $\mathrm{H}_{2} \mathrm{O}$ is generally inert towards ligand activation reactions [see ref. $4 \mathrm{c}$ ].

23 (a) A. Noll, U. Müller, Z. Anorg. Allg. Chem. 625 (1999) 1721.

(b) B. M. Bulychev, V. K. Bel'sky, Russ. J. Inorg. Chem. 42 (1997) 260. 
(c) F. A. Cotton, S. A. Duraj, W. J. Roth, Acta Crystallogr. C 41 (1985) 881.

(d) F. A. Cotton, R. C. Najjar, Inorg. Chem. 20 (1981) 1866.

24 E. König, Magnetische Eigenschaften der Koordinations- und Metallorganischen Verbindungen der Übergangselemente in Landolt-Börnstein, Zahlenwerte und Funktionen aus Naturwissenschaften und Technik, 6th Ed., Springer-Verlag, Berlin, Göttingen, Heidelberg, 2 (1966) 16.

25 W. Willker, D. Leibfritz, R. Kerssebaum, W. Bermel, Magn. Reson. Chem. 31 (1993) 287.

26 D. A. Skoog, D. M. West, Fundamentals of Analytical Chemistry, 2nd Edition, Holt, Rinehart and Winston, Chatham, UK (1974) 233.

27 G. M. Sheldrick, SHELX97-Program for the refinement of Crystal Structures, University of Göttingen, Germany (1997). 
